\title{
Assessment of Biotic Integrity in Streams of Biological Reserve of Una, Bahia, Brazil
}

\author{
Teodosio Andressa Santos ${ }^{1 *}$ and Flores-Lopes Fábio ${ }^{2}$ \\ ${ }^{1}$ Tropical Aquatic Systems of the DCB/UESC, Universidade Estadual de Santa Cruz, Rodovia Jorge Amado, km 16, CEP 45662-900, \\ Ilhéus, BA, Brazil \\ 2Department of Biological Sciences,UESC, Universidade Estadual de Santa Cruz, Rodovia Jorge Amado BA-415, km 16, CEP \\ 45662-900, Salobrinho, Ilhéus, BA, Brazil \\ *Corresponding Author
}

Received: 23rd May, 2020

Accepted: 24th June, 2020

Published online: $6^{\text {th }}$ July, 2020

https://doi.org/10.33745/ijzi.2020.v06i02.001

\begin{abstract}
The objective of this study was to evaluate the environmental quality of streams of the Biological Reserve of Una through the Biotic Integrity Index (IBI). Integrated quality index (IQI) and the Habitat Assessment index (HAI) were used for validation of the IBI. These indices were calculated from attributes of fish community. Four seasonal collections were performed with a seine net at seven sampling points. A total of 5549 individuals were collected from 4 orders, 9 families and 22 species. According to IBI, point 7 could be considered as having good environmental quality, points 1, 2 and 5 of regular quality, points 3 and 4 as poor and point 6 as very poor quality. The results were considered similar to those obtained by HAI and IQI, indicating that points 1, 2, 5 and 7 had a better environmental quality than point 6 . No point were classified as excellent, suggesting a possible environmental degradation in the reserve. The attributes "Richness of benthic species", "Richness of nectonic species" and "Per centage of individuals with anomalies and diseases" did not significantly influence the index result, and the other parameters appeared to be more effective. The IBI was considered an useful tool in the environmental evaluation of the region since it was sensitive to the gradient of degradation of the points sampled.
\end{abstract}

Keywords: Environmental assessment, Biological reserve, Fishes, Biotic integrity index

Citation: Teodosio A.S. and Flores-Lopes Fábio: Assessment of biotic integrity in streams of biological reserve of Una, Bahia, Brazil. Intern. J. Zool. Invest. 6 (2): 217-232, 2020. https://doi.org/10.33745/ijzi.2020.v06i02.001

\section{Introduction}

Environmental conditions of rivers in Brazil is associated by structural maintenance and consequent preservation of the environment (Pinto et al., 2006) and indicate dramatic changes in the quality of streams, primarily due to sewage emission. Cetra and Ferreira (2016) demonstrated a relation between environmental quality of streams and 
biological integrity of fish assemblages. Environmental monitoring programs are seen as a way of understanding the causes of pollution, as well as quantifying trends in the level of contaminants and how they enter the atmospheric, aquatic and terrestrial compartments (Pearce and Despres-Pantajo, 1988).

Indices of biotic integrity (IBIs) based on fish assemblage structure, which were first introduced by Karr (1981), has been widely accepted as a tool to classify the quality of aquatic environments (Belpaire et al., 2000), with fish being the most visible and sensitive components of aquatic ecosystems, various attributes make them useful indicators of biological integrity and ecosystem health (Fausch et al., 1990). Verdonschot et al. (2000) stated that IBIs offer more comprehensive assessments than other biotic indicators based solely on species richness, diversity indices, indicator species, or multivariate analyses In addition, understanding how biological communities distribute themselves in the natural environment enables management and actions that minimize the degradation of these ecosystems (Karr et al., 1986).

The inclusion of IBI in monitoring programs can be used to detect spatial and temporal trends in water quality and is an efficient instrument in the conservation and management programs of Brazilian aquatic ecosystems (Araújo, 1998). On the other hand, considering the annual ecological differences that occur in the tropics, it would be interesting to evaluate the temporal variation for many years in the same locality, in the same season (Roset et al., 2007). This approach would allow understanding and dimensioning the internalization of long-term environmental variation in biota (JamarilloVilla and Caramaschi, 2008).

Originally developed for the evaluation of the ichthyofauna in streams of temperate climate of the Midwest of the United States, the IBI has been adapted to regions of tropical climate. In many of Brazilian ecosystems, the application of IBI is limited by the lack of systematic knowledge of the species (Buckup et al., 2007) as well as the difficulty of finding fully conserved watercourses to serve as a reference, especially in non-amazonian areas (Casatti et al., 2008). The lack of knowledge about fish fauna and environmental changes in neotropical regions are a concern to ichthyologists and ecologists, since regional biodiversity may disappear from some rivers even before the species are known (TerejinaGarro, 2008).

According to Ferreira (2010), the Ichthyofauna generally presents high species richness, low dominance, absence of exotic species and high contribution of allochthonous items (seeds, fruits and terrestrial arthropods) in the diet of its fishes. Cetra and Ferreira (2016) demonstrated a relationship between environmental quality of streams and biological integrity of fish assemblages. Davideanu and Angermeier (2004) stated that the fish community is an excellent indicator of ecosystem health and water is commonly used to assess the quality of rivers. Few studies have realized on freshwater fish in the southern region of Bahia (Cetra et al., 2010). Sarmento-Soares et al. (2005) observed the existence of a diverse fauna, especially endemic species.

The aim of this study was to evaluate the environmental quality of streams in Biological Reserve of Una, using fish communities as an 
assessment tool through the Biotic Integrity Index.

\section{Materials and Methods}

The Biological Reserve of Una (REBIO Una) is an protection conservation unit of the World Patrimony Site, Reserve of the Atlantic Forest of the Discovery Coast, which is part of the Biosphere Reserve of the Atlantic Forest. It has an area of 11.400 ha and a perimeter of 52 $\mathrm{km}$, created on October 10, 1980 by Decree No. 85463 is limited to the northeast by the Maruim river and by right arm by Bandeira river (MMA, 1997). Fully inserted in the municipality of Una, the reserve still has as influence areas, due to the proximity and access roads, the municipalities of Itabuna, Ilhéus, Buerarema and Arataca.

Four seasonal samplings were performed, collected using a seine net $(5.5 \mathrm{~m} \times 1.5 \mathrm{~m}$; mesh size $0.5 \mathrm{~cm}$ ) (Malabarba and Reis, 1987), from February 2011 to March 2012, in seven points in Biological Reserve of Una: Point 1 São Caetano stream (3903'36" W - 1512'34" S); Point 2 - Rosário riverside $\left(39^{\circ} 04^{\prime} 24^{\prime \prime} \mathrm{W}\right.$ $\left.15^{\circ} 13^{\prime} 04^{\prime \prime} \mathrm{S}\right)$; Point 3 - Serra river $\left(39^{\circ} 04^{\prime} 32^{\prime \prime}\right.$ W - 15'13'52" S); ponto 4 - Maruim river

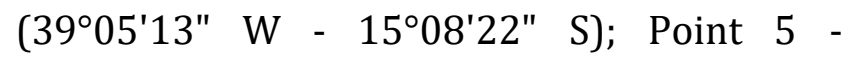

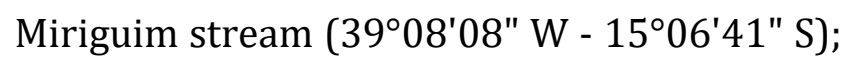

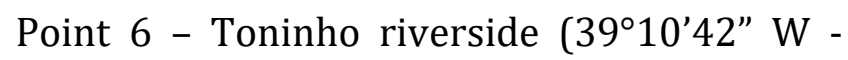
$\left.15^{\circ} 07^{\prime} 17^{\prime \prime} \mathrm{S}\right)$; Point 7 - Vila Brasil (3909'31" W - $15^{\circ} 05^{\prime} 38^{\prime \prime}$ S) (Fig. 1). Each point realized standardized samplings with 6 margin trawls.

Some specimens were anesthetized with MS222 (3-Aminobenzoic Acid Ethyl Ester) and preserved in $10 \%$ formalin. In the laboratory the material was sorted and identified to the species level and preserved in 70\% alcohol. Some specimens were sent to experts at the Federal University of Rio Grande do Sul (UFRGS) and Museum of Zoology at Pontifícia
Catholic University of Rio Grande do Sul (PUCRS) for identification. An analysis was performed to verify the presence of morphological abnormalities and the presence of ectoparasites in all the individuals sampled. Subsequently the material was deposited in the scientific collection of the State University of Santa Cruz (UESC).

\section{Biotic Integrity Index (IBI)}

The Biotic Integrity Index (IBI) was calculated from an adaptation of the method proposed by Karr (1981) due to the different characteristic of the species collected, the structural difference of the environments analyzed, the absence of specimens of some characteristics, the lack of decent ichthyological information on some of the present species, etc. It was originally based on twelve attributes of the fish community in order to evaluate the environmental quality of the points sampled. These attributes were adapted and defined from the characteristics of the fish community in the region and grouped into three categories: Composition and Species Richness, Trophic Composition and Abundance of Fish, and Condition (Table 1).

The attribute "Number of Sunfish Species", which are not observed in the region, was replaced by "Per cent Characiformes and Siluriformes". The proportion of species belonging to these orders in conserved continental waters of the Neotropical region is well known, however, under degraded conditions the environment can be dominated by more tolerant species of the orders Perciformes and Cyprinodontiformes.

The attribute "Number of native species", originally proposed by Karr (1981), was replaced by "Proportion of individuals of 


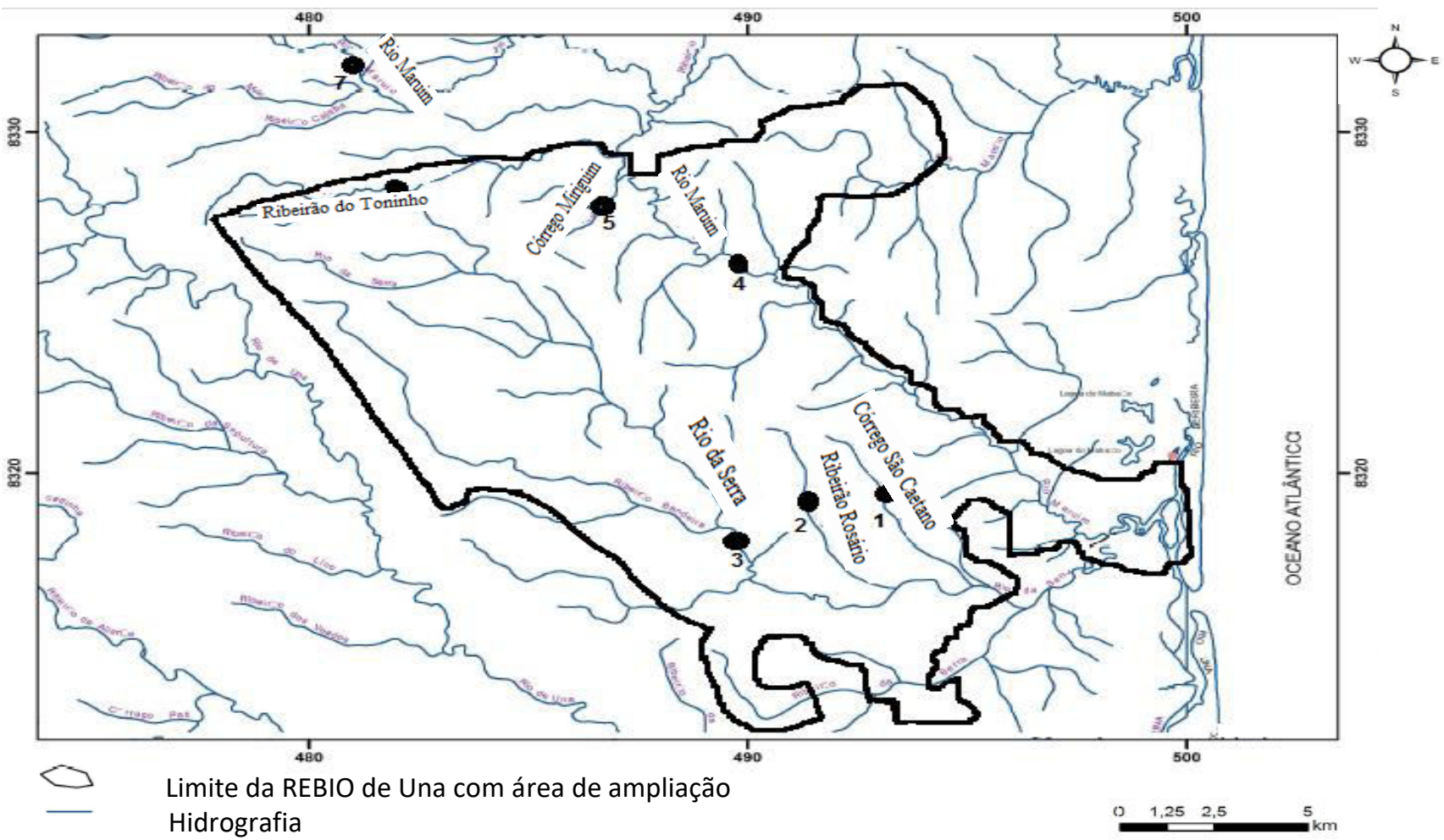

Figure 1: Map of Biological Reserve of Una with the location of the sampling points. Modified by Landau et al. (2003).

Table 1: Originals and adapted metrics for the Index of Biotic Integrity (IBI) and the expected response to an increase in environmental degradation

\begin{tabular}{lll}
\hline \multicolumn{1}{c}{ Originals metrics (Karr, 1981) } & \multicolumn{1}{c}{ Adapted metrics } & Response \\
\hline $\begin{array}{l}\text { Species richness and composition } \\
\text { 1-Number of sunfish species }\end{array}$ & 1-Per cent of Characiform and Siluriform & Reduces \\
2-Number of darters species & 2-Benthonics species richness & Reduces \\
3-Number of water column species & 3-Nekthonics species richness & Reduces \\
4-Number of intolerant species & 4-Species richness & Reduces \\
5-Numbers of native species & 5-Proportion of individuals of exotic species & Increases \\
Trophic composition & & \\
6-Number of sucker species & 6-Per cent herbivores/detritivores & Reduces \\
7-Per cent top carnivores & 7-Per cent carnivores & Reduces \\
8-Per cent omnivores & 8-Per cent omnivores & Increases \\
9- Per cent insectivores & 9-Per cent invertivores & Reduces \\
Fish Abundance and Condition & & \\
10-Per cent DELT abnormalities & 10-Per cent individuals with abnomalities & Increases \\
11-Per cent hybrids & 11-Per cent individuals with black spot & Reduces \\
12-Number of individuals & disease & \\
\hline
\end{tabular}


exotic species" due to the lack of knowledge of the species in this drainage-basin. The calculation of the scores was based on the number of individuals sampled during the study period. The attribute "Number of Sucker Species" was replaced by "Per cent herbivores/detritivores" according to Harris and Silveira (1999), since these species make the index more sensitive to changes in the river's geomorphology through the specialization of these fish into the habitat.

Regarding the fourth attribute, "Number of Intolerant Species", due to a lack of knowledge about the tolerance of neotropical species to the factors influencing the condition of the environment, this attribute was replaced by "Species richness".

The attributes "Numbers of individuals", "Per cent top carnivores", "Per cent omnivores", "Nectonics", "Benthics" and "Per cent DELT Abnormalities" were used without modification. The attribute "Per cent Insectivores", due to the lack of occurrence of this group in this region, was replaced for the per cent of "Invertivores". The attribute "Per cent Hybrids", due to the lack of knowledge about the response of this attribute to the environmental condition in the region, was replaced by "Per cent individuals with black spot disease" (PP), according to Flores-Lopes and Thomaz (2011) (Table 1).

\section{Attribute Scoring}

Each attribute was given a score of 5 (good situation), 3 (regular situation) and 1 (bad situation), being the place classified in four classes of water quality (Good, Moderate, Poor and Very Poor), according to the degradation response shown in Table 1. The value of the biotic integrity index was determined from the sum of the scores of all the attributes and then classified in one of the five categories of biotic integrity (Ferreira and Casatti, 2006).

\section{IBI validation}

In order to valídate, the IBI was calculated by the Integrated Quality Index (IQI), as described in Bruschi Jr. et al. (2000), and was made an evaluation of the environment with the Habitat Assessment Index (HAI), based on a rapid assessment protocol of habitat diversity as described in Vieira and Shibatta (2007). This protocol consists of a score on a scale of 0 to 3 (where $0=$ poor; $1=$ median; 2 = suboptimal; 3 = optimal) for each of the eleven habitat parameters measured -- 1 Bottom type; 2 - Width of backwaters; 3 Frequency of backwaters; 4 - Types of substrate; 5 - Deposition of mud; 6 - Sediment deposition; 7 - Channel alteration; 8 - Water flow characteristics; 9 - Riparian vegetative zone; 10 - Bank stability and 11 - Riparian vegetative zone width. The sum of points obtained for each parameter generates a Habitat Assessment Index (HAI), where the highest score demonstrated the best quality of the aquatic environment analyzed.

The rainfall data were obtained from the Executive Committee of the Cacao Plan (CEPLAC), Cocoa Research Center (CEPEC) in the Climatology sector.

\section{Results}

5549 individuals were collected and distribuited in 4 orders, 9 families and 22 species. The most abundant species was Astyanax burgerai Zanata and Camelier, 2009 with 3896 individuals (70\% of total). The most constant species were Geophagus brasiliensis (Quoy and Gaimard, 1824) (89\%), Astyanax burgerai (86\%) and Astyanax 
fasciatus (46\%). The most abundant order was Characiformes (83\% of total).

The point 2 presented the highest abundance (1910 individuals), followed by the point 3 (926 individuals). The point 5 presented the lowest abundance (283 individuals), followed by point 7 (411 individuals). Point 7 had the highest species richness (15), followed by points 2 and 5 (11), points 3 and 6 presented the lowest richness (8). Astyanax burgerai was the most dominant in all sampling points, except for point 7, whose most dominant species was Astyanax fasciatus.

The Habitat Assessment Index (HAI) ranged from 2 in point 6 to 28 in point 2 . The points that obtained the highest mean of this index were points 2,3 and 7 (25.2, 19.2, 20.2, respectively), being that points 4 and 6 presented the lowest values (5.7 and 4, respectively) (Table 2).

Table 2: Average values of the Habitat Assessment Index (HAI) observed in the Biological Reserve of Una, Bahia

\begin{tabular}{lccccc}
\hline HAI & Sample & Sample & Sample & Sample & Average \\
& $\mathbf{1}$ & $\mathbf{2}$ & $\mathbf{3}$ & $\mathbf{4}$ & \\
\hline Pt 1 & 18 & 18 & 15 & 14 & 16.2 \\
Pt 2 & 28 & 23 & 25 & 25 & 25.2 \\
Pt 3 & 19 & 19 & 17 & 22 & 19.2 \\
Pt 4 & 4 & 6 & 7 & 6 & 5.7 \\
Pt 5 & 15 & 18 & 17 & 15 & 16.2 \\
Pt 6 & 2 & 5 & 5 & 4 & 4 \\
Pt 7 & 19 & 22 & 20 & 20 & 20.2 \\
\hline
\end{tabular}

The highest value of the Integrated Quality Index (IQI) was observed in point 7 (2.22), followed by points 4 and 2 (1.88, 1.87, respectively), and the lowest value was found in point 6 (1.21). According to the results obtained by IQ, only point 7 was considered of high environmental quality, points 2,4 and 5 of medium quality and points 1, 3 and 6 were classified as having low environmental quality
(Table 3). The Integrated Quality Index ranged from 0.95 at point 1 to 2.41 at point 4 . Points 1, 5, 6 and 7 showed no significant difference for this index during the study period.

Table 3: Classification of sampling points in Biological Reserve of Una according to the Integrated Quality Index (IQ)

\begin{tabular}{lcr}
\hline Categories & Range of classes (IQ) & Points \\
\hline Low & $1.21-1.54$ & $1,3,6$ \\
Median & $1.55-1.88$ & $2,4,5$ \\
High & $1.89-2.22$ & 7 \\
\hline
\end{tabular}

The only point considered of good environmental quality according to the Biotic Integrity Index was point 7. Points 1, 2 and 5 presented regular quality, points 3 and 4 were classified as poor and point 6 obtained the lowest score (20), being classified as very poor. No point scored enough to be classified as excellent (Table 4).

According to the classification orders, points 1, 2 and 6 were classified as first order rivers, points 3, 4, 5 and 7 of second and third order. In this way, point 2 obtained the highest IBI score (52), considered excellent. Points 1 and 7 were classified as having good environmental quality, points 3 and 5 were considered regular, point 4 was classified as poor and point 6 had the lowest score (18) and was considered very poor.

When considering the position in the water column, the majority of the species was considered nectonic (15). In relation to the trophic groups of the specimens examined, the majority were of invertivorous species (10) and according to the origin of the individuals, most were native species (19) (Table 5).

The per centage of Characiformes and Siluriformes ranged from 52.1 at point 6 to 
Table 4: Result and classification of IBI for each sampling point during the study period

\begin{tabular}{|c|c|c|c|c|c|c|c|}
\hline \multirow[t]{2}{*}{ Metrics } & \multicolumn{7}{|c|}{ Points } \\
\hline & 1 & 2 & 3 & 4 & 5 & 6 & 7 \\
\hline 1- Per cent of Characiformes and Siluriformes & 5 & 5 & 5 & 3 & 5 & 1 & 3 \\
\hline 2- Benthonics species richness & 3 & 5 & 3 & 1 & 3 & 3 & 5 \\
\hline 3- Nekthonic species richness & 3 & 1 & 1 & 5 & 5 & 1 & 5 \\
\hline 4- Species richness & 3 & 3 & 1 & 3 & 3 & 1 & 5 \\
\hline 5- Proportion of individuals of exotic species & 5 & 5 & 5 & 1 & 5 & 1 & 3 \\
\hline 6- Per cent herbivores/detritivores & 1 & 1 & 3 & 1 & 1 & 1 & 5 \\
\hline 7-Per cent carnivores & 3 & 1 & 1 & 3 & 5 & 1 & 5 \\
\hline 8-Per cent omnivores & 5 & 5 & 5 & 3 & 5 & 1 & 1 \\
\hline 9-Per cent invertivores & 5 & 5 & 5 & 3 & 5 & 1 & 1 \\
\hline 10-Per cent individuals with abnormalities & 5 & 5 & 3 & 5 & 1 & 5 & 5 \\
\hline 11- Per cent individuals with black spot disease & 1 & 1 & 3 & 1 & 1 & 1 & 5 \\
\hline 12-Number of individuals & 3 & 5 & 5 & 3 & 1 & 3 & 1 \\
\hline IBI & 42 & 42 & 34 & 32 & 40 & 20 & 44 \\
\hline Categories & $\mathbf{M}$ & $\mathbf{M}$ & $\mathbf{P}$ & $\mathbf{P}$ & $\mathbf{M}$ & VP & $\mathbf{G}$ \\
\hline
\end{tabular}

98.4 at point 3 . The richness of benthic species ranged from 0 at point 4 to 5 at point 7 . The richness of nectonic species ranged from 6 at Points 2, 3, 6 to 10 at points 4 and 7. Species richness varied between 8 at points 3 and 6 and 15 at point 7 . The per centage of individuals of exotic species ranged from 0 at points 1,2 and 3 to 35.2 at point 4 . The per centage of scrapers ranged from 0.1 to 19.5 at points 3 and 4 . The per centage of carnivores ranged from 0.1 at point 2 to 2.2 in point 7 . The per centage of omnivores ranged from 1.6 at point 3 to 47.9 at point 6 . The per centage of invertivores varied between 42.6 in Point 7 and 96.8 in point 3 . The number of individuals with anomalies and diseases varied between 1 in points 3 and 5 or 0 in the other points. The per centage of individuals with black spots disease ranged from 1.7 in point 6 to 20.6 in point 7 (Tables 4, 6).

Regarding the temporal variation, in points 1, 2, 3 and 4, the highest IBI values were observed in November 2011 (third collection), with the highest cumulative precipitation $(250 \mathrm{~mm})$. At point 5 , this month the lowest IBI value was observed and in the months of February and July 2011 the highest values. However, in these months the lowest IBI values were observed in points 1, 2, 3, and 7 and the accumulated precipitation (124 and $175 \mathrm{~mm}$, respectively). The point 7 showed a small gradual increase during the first three collections and a heavy increase in the last collection, point 6 remained constant.

The attributes that most influenced the increase in biotic quality in the third collection 
Table 5: Classification of sampled species according to attributes related to position in the water column, trophic group and origin

\begin{tabular}{|c|c|c|c|}
\hline Order/Species & Position & Trophic group & Origin \\
\hline \multicolumn{4}{|l|}{ Characiformes } \\
\hline Astyanax bimaculatus & Nektonic & Invertivorous & Native \\
\hline Astyanax burguerai & Nektonic & Invertivorous & Native \\
\hline Astyanax aff. Fasciatus & Nektonic & Invertivorous & Native \\
\hline Astyanax sp. & Nektonic & Invertivorous & Native \\
\hline Characidium sp. & Benthonic & Invertivorous & Native \\
\hline Hoplerythrinus unitaeniatus & Nektonic & Carnivorous & Native \\
\hline Hoplias malabaricus & Nektonic & Carnivorous & Native \\
\hline Hoplias sp. & Nektonic & Carnivorous & Native \\
\hline Hyphessobrycon luetkenii & Nektonic & Invertivorous & Native \\
\hline Oligossarcus macrolepis & Nektonic & Carnivorous & Native \\
\hline Oligosarcus sp & Nektonic & Carnivorous & Native \\
\hline \multicolumn{4}{|l|}{ Cyprinodontiformes } \\
\hline Poecilia reticulata & Nektonic & Omnivorous & Exotic \\
\hline Poecilia vivípara & Nektonic & Omnivorous & Exotic \\
\hline \multicolumn{4}{|l|}{ Perciformes } \\
\hline Geophagus brasiliensis & Nektonic & Omnivorous & Native \\
\hline Geophagus sp. & Nektonic & Omnivorous & Native \\
\hline \multicolumn{4}{|l|}{ Siluriformes } \\
\hline Aspidoras sp. & Benthonic & Invertivorous & Native \\
\hline Awaous taiasica & Benthonic & Invertivorous & Native \\
\hline Callichthys callichthys & Benthonic & Invertivorous & Native \\
\hline Pareiorhaphis bahianus & Benthonic & Herbivorous/detritivorous & Native \\
\hline Rhamdia sp. & Benthonic & Omnívoro & Native \\
\hline Rineloricaria sp. & Benthonic & Herbivorous/detritivorous & Native \\
\hline Scleromystax lacerdai & Benthonic & Invertivorous & Native \\
\hline
\end{tabular}

in points 1, 2 and 3 were "Benthic species richness", "Species richness" and "Per centage of individuals with "Black Spot Disease". In addition to these, point 3 was also influenced by the "Per centage of individuals of exotic species". In point 4 , the "Per centage of Characiformes and Siluriformes", "Per centage of individuals of exotic species" and "Per cent of omnivores" were the attributes that most influenced the heavy increase of the index. In point 7, the parameters "Species richness", "Per centage of carnivores" and "Per centage of individuals with Black Spot disease" were the parameters that most influenced during the fourth collection. The attributes that contributed to the decrease of the environmental quality in point 5 in the third collection were "Richness of nectonic species", "Richness of benthic species" and "Species richness".

\section{Discussion}

According to Cetra and Ferreira (2016), several studies demonstrated a relation between environmental quality of streams and biological integrity of fish assemblages 
Table 6: IBI metrics and scoring criteria for Biological Reservation of Una, Bahia

\begin{tabular}{lccc}
\hline \multicolumn{1}{c}{ Metric } & \multicolumn{2}{c}{ Scoring criteria } \\
\hline & $\mathbf{1}$ & $\mathbf{3}$ & $\mathbf{5}$ \\
1- Per cent of Characiformes and Siluriformes & $<63.5$ & $63.5-82.9$ & $>82.9$ \\
2- Benthonics species richness & $<2$ & $2-3$ & $>3$ \\
3- Nekthonics species richness & $<7$ & $7-8$ & $>8$ \\
4-Species richness & $<10$ & $10-12$ & $>12$ \\
5- Proportion of individuals of exotic species & $>235$ & $11.7-23.5$ & $<11.7$ \\
6- Per cent herbivores/detritivores & $<6.5$ & $6.5-12$ & $>12$ \\
7-Per cent carnivores & $<0.8$ & $0.8-1.5$ & $>1.5$ \\
8-Per cent omnivores & $>32.4$ & $17-32.4$ & $<17$ \\
9-Per cent invertivores & $<60.7$ & $60.7-78.8$ & $>78.8$ \\
10-Per cent individuals with abnormalities & $>02$ & $0.1-0.2$ & 0 \\
11- Per cent individuals with black spot disease & $<6.3$ & $6.3-12.3$ & $>12.3$ \\
12-Number of individuals & $<534$ & $534-926$ & $>926$ \\
\hline
\end{tabular}

and it can be used as an indicator for assessing and monitoring the quality of water bodies. Machado et al. (2011) accentuated that the Index of Biotic Integrity is an instrument used in various places in the world as a way to evaluate environmental impacts in aquatic communities.

Araújo (1998) stated thatit is unlikely that a single number could reflect in a comprehensive and adequate manner all the existing variability, whether natural and/or caused by anthropic influence, however, can be very useful in environmental monitoring programs since it provides important information, based on parameters of the fish fauna, for decision making by environmental institutions. The Biotic Integrity Index proved to be an efficient tool for environmental assessment of the region of Biological Reserve of UNA, due to its sensitivity to the different degrees of degradation observed. Studies in conjunction with other methodologies are needed to elucidate factors still pending in this region and to make a more consistent diagnosis.

In this study it was observed that the points 1, 2, 5 and 7 were the ones that presented the best environmental quality according to IBI, and the results are in line to those observed in the HAI, probably due to the fact that these environments are more preserved, in these places it was possible to verify the occurrence of minor alterations in the river channel, greater amount of riparian vegetation, less amount of pastures and less erosive margins. Agostinho et al. (2005) reported that these alterations are among the main factors that hinder the conservation of biodiversity in Brazilian inland waters. These results also mostly agree with IQI results, in which the highest value was observed at point 7 , followed by points 2,4 and 5 and the lowest value was found at point 6 .

The IBI results showed that point 7 had the best environmental quality, unique located outside the UNA reservation. Point near the 
urban perimeter of the community Vila Brasil, despite presenting large amounts of riparian vegetation and little modification in its surroundings, demonstrated anthropogenic activity such as the dumping of detergent and domestic sewage, constant activities that directly influenced the HAI. It was considered the point of greatest environmental quality by IBI and IQI since it presented the highest species richness and the highest diversity index, factors that influenced the IQI result. Present results similar are to those reported by Leidy and Fielder (1985), who found that both species richness and diversity increase in places subject to a moderate human disturbance. According to Fausch et al. (1990), community attributes decline with severe degradation, but species richness and diversity tend to increase even in places with less or moderate degradation due to a possible increase in food supply and habitats.

An apparently preserved site, with a large amount of marginal vegetation and little anthropic activity, the point 3, presented one of the highest HAI values. However, the lowest species richness and an individual with anomaly were observed, which contributed to their low IBI and IQI classification. This information indicating that this site may be under influence of some stressor agent not identified in the present study.

The Point 4 is the most visibly modified, dammed, of very degraded riparian forest, a large amount of pasture in its surroundings and in a very advanced silting process, presented one of the lowest values in HAI. Its characteristics make it a lentic and shallow environment in which the sample effort is facilitated, which may have an influence on the quantity of individuals and species collected, making its classification in IQI. In addition, point 4 presented the highest per centage of exotic species Poecilia reticulata and Poecilia vivipara, considered by Aquino et al. (2009) as indicators of quality in streams due to their tolerance to impacted habitats and environmental variations, occurring in places where a large number of species have a limited distribution (Araújo et al., 2003). According to Kennard et al. (2005) the occurrence of tolerant species in great abundance mainly belonging to the family Poecilidae may be related to the loss of watercourse integrity. IBI was very sensitive to this attribute (Per centage of exotic species), which contributed to the fact that this point was classified as poor by this index.

On the other hand, point 6 presented the worst environmental quality, being considered very poor by the IBI and of low quality by the IQI and obtained the lowest score in the HAI. The greatest environmental degradation at this point may be due to the anthropic action. Inside a farm this point presents the highest amount of pastures, modifications in its surroundings, very little amount of riparian vegetation and in an advanced process of silting.

The fact that no point within the reserve obtained sufficient score in the general IBI to be classified as excellent indicates a possible environmental degradation in the reserve. The results obtained agree with the observations made in the field, where it was possible to observe a greater amount of pasture, human occupation, effluent removal and domestic detergents and changes in river banks than expected for a biological reserve. Several authors, such as Araújo (1998), Bozzetti and Schulz (2004), Ferreira and Casatti (2006). Pinto and Araújo (2007), Paulo et al. (2012, 2020), and Reuss-Strenzel (2011), Flores- 
Lopes and Thomaz (2011) and Flores-Lopes et al. $(2019,2020)$ when carrying out studies in different environments in Brasil, verified the occurrence of several environmental changes due to human activity, and several of them used the IBI as a form of environmental assessment.

Similar results were observed by Castro et al. (2012) that reveal a series of common threats in the Brazilian Conservation Units, such as artificial limits, insufficient sizes and lack of resources for management and effective control programs. In addition, in most protected areas, land tenure problems, agriculture, livestock and the exploitation of forest resources and hunting are frequent (Volcan et al., 2009). Despite being an integral conservation unit, these threats were identified in the Biological Reserve of Una, which may explain the low environmental quality found.

In rivers, the wealth of the local assembly usually increases along the upstream/downstream gradient, often attributed to the increase in size and diversity of downstream habitats or increase in food sources, or both (Grenouillet et al., 2002). In tropical streams, this pattern has been associated with an increase in habitat heterogeneity, which, in turn, is mainly related to an increase in flow and availability of coats (Garutti, 1988).

The IBI was sensitive to this fluvial hierarchy. When sorted by order of the river, the classification of point 1 changed from regular to good, from point 2 from regular to excellent and that from point 6 remained as very poor. The attributes that most contributed to this were "Per centage of individuals with Black Spot disease". The attribute "Per centage of scrapers", which obtained higher scores due to noncomparison with other points, such as 7 , is characterized by rapid water and stony bottom, characteristics more favorable to scraping individuals when compared to lentic environments such as the first order 7 (Casatti, 2005).

These results were corroborated by the field observations and the results obtained by IQI and HAI, since point 2 presented a higher amount of marginal vegetation and lower amount of pasture and anthropic activities than point 1 . This point showed part of its canalized, indicating a lower environmental quality of this point when compared to point 2. The classification of point 3 , according to the second and third order segments, went from poor to regular, and the others maintained the general classification. These results were maintained according to the HAI, where at the point 3 it is possible to observe a considerable amount of marginal vegetation and little change in its surroundings, and apparently presented an environmental quality superior to point 4 .

The period of greatest rainfall presented the highest IBI values in relation to the dry period, indicating the possibility of a better environmental quality in the rainy season. Sarmento-Soares et al. (2008) obtained similar results in this type of analysis. Usually IBI studies do not assess seasonal variations on index values, mainly because did not record any temporal dependence (JaramilloVilla and Caramaschi, 2008), and present results are similar to those of Bozzetti and Schulz (2004) and Ferreira and Casatti (2006) which had little temporal influence on this index. 
At the points 1, 2 and 3, the attributes that contributed most to the results were: "Richness of benthic species", "Richness of species" and "Per centage of individuals with Black Spot Disease". According to Barbieri and Kronemberg (1994), results such as this may be due to a greater supply of food with the greater input of organic matter and sediments originated from the leaching of the soil by the rains, favoring the occurrence of more species. The period of higher rainfall favors the increase of river flow, which in addition to promoting a greater dilution of domestic and industrial effluents, leads to an increase in water quality (Ballester et al., 1999), which favors (Galli et al., 2001). The attributes that contributed to the decrease of the environmental quality at point 5 were those related to the number of species, which may be due to the greater difficulty of sampling in that period added to the fact of being the point of greater depth.

The predominance of the orders Characiformes and Siluriformes in the ichthyofauna reflects the expectation for Atlantic river systems (Barreto and Aranha, 2005). In degraded conditions the environment can be dominated by more tolerant species of Perciformes and Cyprinodontiformes (Casatti, 2005) such as Poecilia vivipara and Poecilia reticulata. The attribute "Per centage of Characiform and Siluriformes species" obtained the lowest scores at points 4 and 6 , considered as the ones with the lowest environmental quality and proved to be very efficient for assessing the environmental quality of this region.

Low soil cover causes erosive processes, which has a direct effect on water column species. Active swimmers with varied feeding are sensitive to high concentration of suspended matter and habitat degradations, which also affects the species most closely associated with the bottom, as this becomes more silt and homogeneous with the increase of the sedimentation (Ferreira and Casatti, 2006). The attributes "Richness of benthic species" and "Richness of nectonic species" seem to cancel out when used at the same time in this region. Although they are sensitive to environmental degradation, their non-use does not seem to affect IBI.

The points that presented the smallest sums of the attributes "Richness of species" and "Number of individuals" were the 4, 5 and 6 , the lower value of these metrics at point 5 may be due to the greater difficulty of sampling caused by the depth of this stretch, whereas at points 4 and 6 it may be due to the lower quality. Combined with diversity measures, "Species richness" and "Number of individuals" are widely used for the assessment of aquatic ecosystems (Casatti et al., 2008). These are metrics that tend to increase with better environmental quality (Karr et al., 1986) and one of the most used of the original metrics proposed by Karr (1981). To complement the answer given by these attributes, Ferreira and Casatti (2006) also included the Simpson's diversity index.

The attributes "Per centage of scavengers", "Per centage of carnivores", "Per cent of omnivores", and "Per centage of invertivores", used together proved to be good environmental indicators and sensitive to environmental degradation. The trophic metrics reflect the degree of change in the food chains, being an important category and widely used in evaluations with the IBI. The omnivores are found in abundance in polluted places, these species use a great variety of foods and their occurrence corroborates the 
classification of sites of intermediate or low quality (Bruschi Jr. et al., 2000). The specialist species indicate a diverse trophic chain, since they depend on a well-structured trophic network (Karr, 1981). The introduction of exotic species is among the most common causes of extinction of species in aquatic environments (Agostinho et al., 2005), due to competition for food, shelter, the spread of parasites and the absence of natural predator. The lower scores for the attribute "Per centage of individuals of exotic species" contributed to the indication of the sites of worse environmental quality, and similar results were observed for Araújo et al. (2003) and Ferreira and Casatti (2006).

Two individuals with morphological abnormalities (spinal torsion) were found, one at point 3 and one at point 5. Although this is an additional reason for alerting to the environmental quality of the reserve, these individuals may be occasional, and it shows that the attribute "Per centage of individuals with anomalies and diseases" may not be representative for the region, since levels are not verified contamination by domestic or industrial sewage discharges, factors associated with the highest deformity (Sanders et al., 1999). Other authors found very low or no incidence of individuals with visible abnormalities (Araújo, 1998; Ganasan and Hughes, 1998).

The attribute "Per centage of individuals with "Black Spot disease" was also a good indicator of environmental quality. FloresLopes and Thomaz (2011) and Galli et al. (2001) reported an increase in the abundance of digenetic metacercariae (black Spot disease) in waters of higher environmental quality, which suggests that this attribute may be very sensitive to the environmental degradation of the region. The presence of ectoparasites is used in the adaptations of IBI as an indicator of environmental degradation (Araújo, 1998). According to Möller (1987), some pollution conditions favor the propagation of parasites because it exclude their natural predators, reduce host resistance or promote unfavorable living conditions for intermediate hosts.

Marciano et al. (2004) observed that all areas are degradeted or even have been destroyed to accommodate agriculture. Most of the tributaries have suffered drastic structural interventions like canalisations and the removal of riparian vegetation. The decrease of IBI scores in urban areas is principally caused by physical degradation of the aquatic environment (Costa and Schulz, 2010). Esteves and Alexandre (2011) showed that the sites within the agricultural areas where sugarcane fields were dominant supported biologically diverse fish communities, urban areas, especially at the dry season. Results of this study suggest that stream integrity is declining, especially at the urban sites, due to the modifications of habitat and/or water quality deterioration. The lack of ciliary vegetation facilitates the silting and destruction of microhabitats used for food and shelter, a fact that prevents the presence of many of these species in degraded places (Melo et al., 2004).

The results of this study and the results obtained by Flores-Lopes et al. (2010) and Flores-Lopes and Thomaz (2011) revealed the need to use more than one methodology as a tool to assess the environmental quality. Depending on the complexity of relationships among physical, chemical and biological processes that make up the aquatic environment, a wider range of methodologies 
is indispensable so that a diagnosis can be more consistent about the real conditions of the watershed that is being studied. Eaton and Lydy (2000) demonstrated the importance of using multiple attempts to assess water quality. According to them, the use of only one method is a mitigation of physical, chemical and biological water relations.

\section{Acknowledgement}

The authors thank the State University of Santa Cruz (UESC) for providing facilities and resources; and the National Council for Scientific and Technological Development (CNPq) for sponsoring this research project.

\section{References}

Agostinho AA, Thomaz SM and Gomes LC. (2005) Conservation of the biodiversity of Brasil's inland waters. Conservation Biol. 19: 646-652.

Aquino P PU, Schneider M, Silva MJM, Fonseca PA, Arakkawa BH and Calvacanti DR. (2009) Ictiofauna dos Córregos do Parque Nacional de Brasília, Bacia do Alto Rio Paraná, Distrito Federal, Brasil Central. Biota Neotropica 9: doi.org/10.1590/S167606032009000100021.

Araújo FG. (1998) Uso da Taxocenese de Peixes como Indicadora de Degradação Ambiental no Rio Paraíba do Sul, Rio de Janeiro, Brasil. Brazilian Archives Biol. Technol.. 41: 370-378.

Araújo FG, Fichberg ., Pinto BCT and Peixoto MGA. (2003) Preliminary index of biotic integrity for monitoring the condition of the Rio Paraiba do Sul. Environ. Manage.. 32: 516-526.

Ballester MV, Martinelli LA, Krusche AV, Victoria RL, Bernardes M and Camargo P B. (1999) Effects of increasing organic matter loading on the dissolved 022 , free dissolved $\mathrm{CO}$ and respiration rates in the Piracicaba river basin, southeast Brazil. Water Res. 33:2119- 2129.

Barbieri EB and Kronemberg DM (1994) Climatologia do litoral sul-sudeste do Estado do Rio de Janeiro: um subsídio à análise ambiental. Cadernos de Geociências 12: 57-74.

Barreto AP and Aranha JM. (2005) Assembléia de peixes de um riacho da Floresta Atlântica: Composição e distribuição espacial
(Guaraqueçaba, Paraná, Brasil). Acta Scientiarum Biol. Sci. 27: 153-160.

Belpaire C, Roelsmolders IV, Auweele D, Ercken J, Breine GV, Thuyne S and Ollevier F. (2000) An Index of Biotic Integrity characterizing fish populations and the ecological quality of Flandrian water bodies. Hydrobiol. 434: 17-33.

Bozzetti M and Schulz UH. (2004) An index of biotic integrity based on fish assemblages for subtropical streams in Southern Brazil. Hydrobiol. 529:133- 144.

Bruschi JrW, Malabarba LR and Silva JFP. (2000) Avaliação da Qualidade Ambiental dos riachos através das Taxocenoses de peixes. In: Carvão e Meio Ambiente (Centro de Ecologia/ufrgs.). Ed. UFRGS, Porto Alegre, p. 1856.

Buckup PA, Menezes NA and Ghazzi MS. (2007) Catálogo das espécies de peixes de água doce do Brasil. Série Livros, Museu Nacional. Rio de Janeiro. p. 195.

Casatti L. (2005) Fish assemblage structure in a first order stream, southeastern Brazil: longitudinal distribution, seasonality, and microhabitat diversity. Biota Neotropica 5:1-15.

Casatti L, Langeani F and Ferreira CP. (2006) Stream fishes, water and habitat quality in a pasture dominated basin, southeastern Brazil. Brazilian Journal Biol. 66: 29-41.

Casatti L, Langeani F, Silva AM and Silva RMC. (2006) Effects of physical habitat degradation on the stream fish assemblage structure in a Pasture Region. Environ. Manage. 38: 974 -982.

Casatti L Ferreira CP and Langeani FA. (2008) Fishbased biotic integrity index for assessment of lowland streams in southeastern Brazil. Hydrobiol. 623:173-189.

Castro AOC, Gomes AA, Batista GVCP and Gonçalves JT. (2012) Os desafios do planejamento e conservação ambiental da Reserva Biológica de Guaratiba (RJ). Revista Nordestina de Ecoturismo 5: 69-76.

Cetra M, Sarmento-Soares L M and Martins-Pinheiro RF. (2010) Peixes de riachos e novas Unidades de Conservação no sul da Bahia. Pan-American J. Aquatic Sci. 5: 11-21.

Cetra M and Ferreira FC. (2016) Fish-based Index of Biotic Integrity for wadeable strems from Atlantic Forest of south São Paulo State, 
Brazil. Acta Limnologica Brasiliensia. 28: doi.org/10.1590/S2179-975X1216.

Costa PF and Schulz UH. (2010) The fish community as na indicator of biotic integrity of the streams in the Sinos River basin. Brasil. Brazilian J. Biol. 70: 1195-1205.

Davideanu G and Angermeier PL. (2004) Using fish communities to assess streams in România: initial development of an index of biotic integrity. Hydrobiol.511: 65-78.

Eaton HJ and Lydy MJ. (2000) Assessment of water quality in Wichita, Kansas, using an index of biotic integrity and analysis of bed sediment and fish tissue for organochlorine insecticides. Archives Environ.l Contam.Toxicol. 39: 531-540.

Esteves K E and Alexandre CV. (2011) Development of an Index of Biotic Integrity based on fish communities to assess the effects of rural and urban land use on a stream in Southeastern Brazil. Internat. Revist Hydrobiol. 96: 296-317.

Fausch KD, Lyons J, Karr JR and Angermeier P L. (1990) Fish communities as indicators of environmental degradation. In: Biological Indicators of Stress in Fish, (ed.) Marshall Adams S., Bethesda, Md: American Fisheries Society.

Ferreira C P. (2010) Estrutura da ictiofauna e integridade biótica de riachos em fragmentos florestais remanescentes no noroeste paulista. Unpublished Ph. D. Dissertaion. Unversidade Estadual Paulista. São José do Rio Petro, p. 167.

Ferreira C and Casatti L. (2006) Influência da estrutura do hábitat sobre a ictiofauna de um riacho em uma micro-bacia de pastagem, São Paulo, Brasil. Revista Brasileira Zool. 23: 642- 651.

Flores-Lopes F, Cetra M and Malabarba LR. (2010) Utilização de índices ecológicos em assembléias de peixes como instrumento de avaliação da degradação ambiental em programas de monitoramento. Biota Neotropica 10: 2- 11.

Flores-Lopes F and Reus-strenzel GM. (2011) Frequency of morphological alterations in the fish of Lake Guaíba and its application to environmental monitoring. Bioikos. 25: 11-23.

Flores-Lopes F and Thomaz AT. (2011) Assessment of environmental quality through analysis of frequency of black spot disease in an assemblage of fish, Guaíba Lake, RS, Brazil. Brazilian J. Biol. 71: 915- 923.

Flores-Lopes F, Brito NC, Cruz AO and Paulo DV. (2019) Histopathology of fish liver to assess the water quality of Limoeiro Stream, Floresta Azul, Ba, Brazil. Intern. J. Zool. Invest. 5: 31-42.
Flores-Lopes F, Correia MA and da Silva DML. (2020) Histological and ultrastructural analysis of Tilapia rendalli liver as an environmental assessment tool for Cachoeira River, Bahia, Brazil. Intern. J. Zool. Invest. 6: 31-48.

Galli P, Crosa G, Mariniello L, Ortis M and D'amelio S. (2001) Water quality as a determinant of the composition of fish parasite communities. Hydrobiol. 452: 173-179.

Ganasan V and Hughes R M. (1998) Application of an index of biological integrity (IBI) to fish assemblages of the Rivers Khan and Kshipra (Madhya Pradesh), India. Freshwater Biol. 40: 367-383,

Garutti V. (1988) Distribuição longitudinal da ictiofauna de um córrego da região noroeste do Estado de São Paulo, Bacia do Rio Paraná. Brazilian J. Biol. 48: 747-759.

Grenouillet G, Pont D and Seip KL. (2002) Abundance and species richness as a function of food resources and vegetation structure: juvenile fish assemblages in rivers. Ecography 25: .641-650.

Harris JH and Silveira R. (1999) Large-scale assessment of river health using a index of biotic integrity with low-diversity fishes communities. Freshwater Biol. 41: 235-252.

Jaramillo-Villa U and Caramaschi E P. (2008) Índices de Integridade Biótica usando peixes de água doce: Uso nas regiões tropical e subtropical. Oecologia Brasiliensis 12: 442-462.

Karr JR. (1981) Assessment of biotic integrity using fish communities. Fisheries 6: 21-27.

Karr JR, Fausch K, Angermeier DPL, Yant PRE and Schlosser IJ. (1986) Assessing the biological integrity in running waters: A method and its rationale. Illinois Natural History Survey Special Publication 5: 28.

Kennard M J, Arthington A H, Pusey BJ and Harch BD. (2005) Are alien fish a reliable indicator of river health? Freshwater Biol. 50: 174-193.

Landau EC, Moura RT, Pinto LPS, Fonseca GAB and Alger K. (2003) Corredor de Biodiversidade da Mata Atlântica do Sul da Bahia. CD-ROM, Ilhéus, IESB/CI/CABS/UFMG/UNICAMP.

Leidy RA and Fielder P L. (1985) Human disturbance and patterns of fish species diversity in the San Francisco Bay Drainege, California. Biol. Conser. 33: 247-267.

Machado NG, Venticinque EM and Penha J. (2011) Effects of environmental quality and mesohabit structure on a Biotic Integrity based on fish 
assemblages of cerrado streams from Rio Cuiabá basin, Brazil. Brazilian J. Biol. 71: 577- 586.

Malabarba L and Reis RE. (1987) Manual de Técnicas para a preparação de ColeçõesZoológicas. № 36 Peixes. Sociedade Brasileira de Zoologia, Campinas. p. 14.

Marciano FT, Chaudhry FH and Ribeiro MCD B. (2004) Evaluation of the index of biotic integrity in the Sorocaba River Basin (Brazil, SP) based on fish communities. Acta Limnol. Brasileira 16: 225- 237.

Melo CE, Machado FA and Pinto-Silva V. (2004) Feeding habits of fish from a stream in the savanna of Central Brazil, Araguaia Basin. Neotropical Ichthyol. 2: 37- 44 .

Möller H. (1987) Pollution and parasitism in the aquatic environment. Internat. J. Parasitol. 17: 353-361.

Paulo DV, Fontes FM and Flores-Lopes F. (2012) Histopathological alterations observed in the liver of Poecilia vivipara (Cyprinodontiformes: Poeciliidae) as a tool for the environmental quality assessment of the achoeira River, BA. Brazilian J. Biol. 72: 131-140.

Paulo DV, Lopes LL, Neves AOC, Magalhães Junior FO, Jesus RM, Braga LGT and Flores Lopes F. (2020) Bioaccumulation, hepatotoxicity, immune response and growth in Oreochromis niloticus exposed to cadmium. Intern. J. Zool. Invest. 6: 1-20.

Pearce J B and Despres-Patanjo L. (1988) A review of monitoring strategies and assessments of stuarine pollution. Aquat. Toxicol. 11: 323-343.

Pinto B CT, Araujo FG and Hughes RM. (2006) Effects of landscape and riparian condition on a fish índex of biotic integrity in a large southeastern Brazil river. Hydrobiol. 556: 69-83.

Roset N, Grenouillet G, Goffaux D, Pont D and Kestemont P. (2007) A review of existing fish assemblage indicators and methodologies. Fisheries Manage. Ecology 14: 393-405.
Sanders RE, Miltner RJ, Yoder CO and Rankin ET. (1999) The use of external deformities, erosion, lesions, and tumors (DELT anomalies) in fish assemblages for characterizing aquatic resources: a case study of seven Ohio streams. In "Assessing the sustainability and biological integrity of water resources using fish communities", (ed. ) Simon TP, CRC Press, Boca Raton, FL, pp 225-248.

Sarmento-Soares LM, Martins-Pinheiro RF, Aranda AT and Chamon CC. (2005) Trichomycterus pradensis, a new catfish from southern Bahia coastal rivers, northeastern Brazil (Siluriformes: Trichomycteridae). Ichtyological Explor. Freshwaters 16: 289-302.

Sarmento-Soares LM, Mazzoni R and Martins-Pinheiro RF. (2008) A fauna de peixes dos rios dos Portos Seguros, extremo sul da Bahia, Brasil. Boletim do Museu Mello Leitão 24: 121-144.

Tejerina-Garro FL, Maldonado, MC, Ibáñez D, Pont Roset N and Oberdorff T. (2005) Effects of natural and anthropogenic environmental changes on riverine fish assemblages: a framework for ecological assessment of rivers. Brazilian Archives Biol. Technol. 48: 91-108.

Vieira D and Shibata O. (2007) Peixes como indicadores da qualidade ambiental do ribeirão Esperança, município de Londrina, Paraná, Brasil. Biota Neotropica. 7. doi.org/10.1590/S167606032007000100008.

Verdonschot PFM, Nijboer RC and Janssen SN. (2000)Ecologische typologie, ontwikkelingsreeksen en waterstreefbeelden Limburg. I: Ruwe indeling in beektypen. Rapport nr. 171.1, Alterrra, Wageningen, p. 116.

Volcan MV, Lanés LEK and Gonçalves AC. (2009) Threatened fishes of the world: Austrolebias nigrofasciatus Costa and Cheffe 2001 (Cyprinodontiformes: Rivulidae). Environ. Biol. Fishes 86: 319-320. 